\title{
A climatology of wintertime low-level jets in Nares Strait
}

\author{
Svenja H.E. Kohnemann \& Günther Heinemann \\ Environmental Meteorology, University of Trier, Trier, Germany
}

\begin{abstract}
Intense, southward low-level winds are common in Nares Strait, between Ellesmere Island and northern Greenland. The steep topography along Nares Strait leads to channelling effects, resulting in an along-strait flow. This research study presents a 30-year climatology of the flow regime from simulations of the COSMO-CLM climate model. The simulations are available for the winter periods (November-April) 1987/88 to 2016/17, and thus, cover a period long enough to give robust long-term characteristics of Nares Strait. The horizontal resolution of $15 \mathrm{~km}$ is high enough to represent the complex terrain and the meteorological conditions realistically. The 30-year climatology shows that LLJs associated with gap flows are a climatological feature of Nares Strait. The maximum of the mean $10-\mathrm{m}$ wind speed is around $12 \mathrm{~m} \mathrm{~s}^{-1}$ and is located at the southern exit of Smith Sound. The wind speed is strongly related to the pressure gradient. Single events reach wind speeds of $40 \mathrm{~m} \mathrm{~s}^{-1}$ in the daily mean. The LLJs are associated with gap flows within the narrowest parts of the strait under stably stratified conditions, with the main LLJ occurring at 100-250 m height. With increasing mountain Froude number, the LLJ wind speed and height increase. The frequency of strong wind events (>20 $\mathrm{m} \mathrm{s}^{-1}$ in the daily mean) for the $10 \mathrm{~m}$ wind shows a strong interannual variability with an average of 15 events per winter. Channelled winds have a strong impact on the formation of the North Water polynya.
\end{abstract}

\section{Keywords}

Arctic; gap flow; atmospheric modelling; Greenland; North Water Polynya; wind

\section{Correspondence}

Svenja H.E. Kohnemann, Environmental Meteorology, University of Trier, Behringstr. 21, DE-54296 Trier, Germany. E-mail kohnemann@uni-trier.de

\begin{abstract}
Abbreviations
AMSR-2: Advanced Microwave Scanning Radiometer, onboard the Global Change Observation Mission for Water-1 satellite; AMSR-E: Advanced Microwave Scanning Radiometer for Earth Observing System, onboard the Aqua satellite; ASR: Arctic System Reanalysis, a multi-agency reanalysis of the Greater Arctic; CCLM: Climate Limited-area Modelling Community Climate Model, also known as COSMO-CLM; ECMWF: European Centre for Medium-Range Weather Forecasts; ERA-Interim: global atmospheric reanalysis data set produced by the ECMWF; ERA5: global atmospheric reanalysis data set produced by the ECMWF replacing ERA-I with a higher resolution; EUMETSAT: European Organization for the Exploitation of Meteorological Satellites; $\mathrm{Fr}_{m}$ : mountain Froude number; GC-NET: Greenland Climate Network; LLJ: low-level jet; MSLP: mean sea-level pressure; NOW: North Water Polynya; OSISAF: Ocean and Sea Ice Satellite Application Facility; PIOMAS: Pan-Arctic Ice Ocean Modelling and Assimilation System, a coupled parallel ocean and sea ice model; RMSE: root mean square error; SIC: sea-ice concentration; SSM/I: Special Sensor Microwave/Imager microwave radiometer system, onboard the US Air Force Defense Meteorological Satellite Programme Block 5D-2 satellites; SSMIS: Special Sensor Microwave Imager/Sounder microwave radiometer system, onboard the US Air Force Defense Meteorological Satellite Programme F-16, F-17, F-18 and F-19 satellites
\end{abstract}

\section{Introduction}

Greenland's high and steep topography is a unique barrier for the atmospheric flow of the Arctic. Large-scale synoptic systems, and topographic and boundary layer processes influence the near-surface winds. Barrier winds on Greenland's east coast are examples of topographically influenced mesoscale wind systems based on larger-scale forcing (Petersen et al. 2009; Harden et al. 2011). Further examples include westerly and easterly tip jets at Cape Farewell (Doyle \& Shapiro 1999; Moore \& Renfrew 2005) and katabatic winds over the slopes of the ice sheet
(Heinemann 1999, 2004; Heinemann \& Klein 2002). Another type of wind system is enhanced winds due to channelling, which is the focus of this research study.

Gutjahr \& Heinemann (2018) showed that Nares Strait is one of the windiest areas in the Arctic, with extremes of about $23 \mathrm{~m} \mathrm{~s}^{-1}$ for the 95th percentile for the daily maximum wind and about $31 \mathrm{~m} \mathrm{~s}^{-1}$ for the 10 -year return level. Nares Strait is located between the north-west coast of Greenland and Ellesmere Island in the Canadian Arctic Archipelagos (Fig. 1). Steep topography bounds this 500-km-long channel. The width of the strait varies from about $25 \mathrm{~km}$ (Robeson Channel) to about $140 \mathrm{~km}$ 

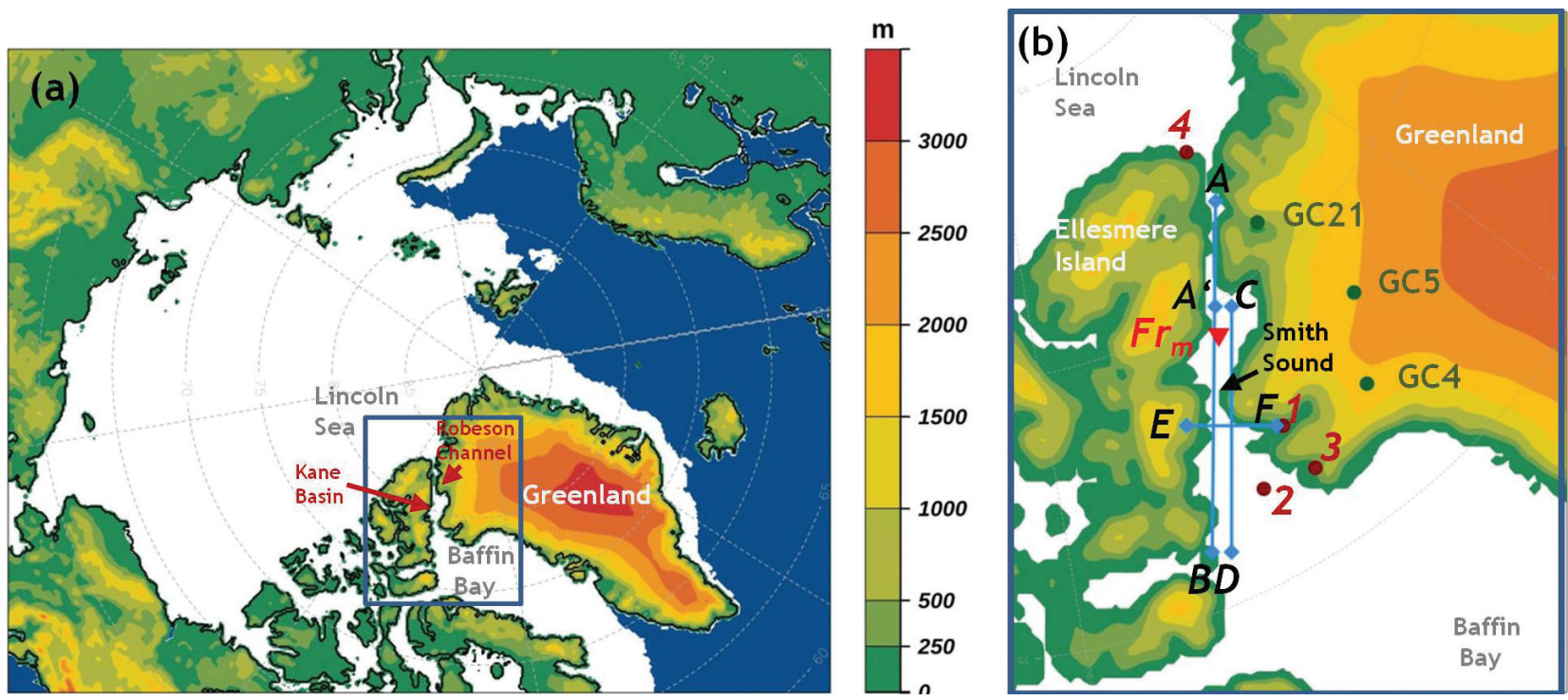

Fig. 1 (a) CCLM 15-km model domain and surface height. Dark blue represents open water, and white shows sea ice on 8 Apr 2014 . (b) Nares Strait with numbers from 1 to 4 indicating the locations of the World Meteorological Organization stations. Lines indicate cross-section positions (A-B, C-D and E-F). The red triangle marks the $\mathrm{Fr}_{m}$ reference point in the Kane Basin. GC4, 5 and 21 represent the locations of the three GC-NET stations: Humboldt Glacier (GC4), GITS (GC5) and Petermann Glacier (GC21).

(Kane Basin). Smith Sound at the southern end of Nares Strait has a width of $40-50 \mathrm{~km}$. In the climatological mean, sea-level pressure is higher at the northern end of Nares Strait, in the Lincoln Sea, than at its southern end, in Baffin Bay. As a result, the terrain in Nares Strait forces the winds in a southward flow, which is accelerated through the smallest passageways, Robeson/Kennedy Channel and Smith Sound. The interaction of stably stratified air with a mountain barrier results in LLJs, which is caused by a "gap flow" (Samelson et al. 2006; Samelson 8 Barbour 2008): the winds blow through a gap because of a pressure difference between the entrance and exit regions of the gap, amplifying the wind speed inside the gap or south of the gap exit (Overland 1984; Gaberšek \& Durran 2004). These channelled winds in Nares Strait can reach gale force; they destroyed an ice camp in Kennedy Channel in April 2005 (Samelson \& Barbour 2008; Melling 2011). Heinemann (2018) presented the first three-dimensional observational data on LLJs for Smith Sound using an aircraft. Well-developed LLJs with wind speeds of up to $22 \mathrm{~m} \mathrm{~s}^{-1}$ were measured, and the pressure difference between the northern and southern end of Nares Strait was between 6 and 13 hPa.

LLJs associated with gap flows are also observed in other regions, such as Svalbard (Barstad \& Adakudlu 2011 ) and the coast of the western USA (Sharp \& Mass 2004). For Nares Strait, orographically channelled flows play a key role in the formation of the NOW, which is the largest ice-producing polynya in the Arctic (Preusser et al.
2016). Preusser et al. (2015) showed that the NOW is subject to significant seasonal changes that affect the overall frequency of polynya occurrences and their spatial extent during the last few decades. The wind regime in Nares Strait is a driver for the sea-ice export from the strait to Baffin Bay, as well as for the ocean circulation (Yao \& Tang 2003; Münchow et al. 2006).

The lack of adequate observational data has made numerical weather and climate models, and reanalyses important tools to study the characteristics of channelled winds in Nares Strait. The steep topography of the strait and the dynamics of LLJs represent a big challenge for realistically simulating the atmospheric processes in this region. Modelling studies of the wind system near Greenland have shown that realistic reproduction strongly depends on the horizontal resolution (Duvivier \& Cassano 2013; Moore et al. 2015). Gutjahr \& Heinemann (2018) stated that a horizontal resolution of at least $15 \mathrm{~km}$ is necessary to capture the extreme wind characteristics near Greenland. Moore \& Våge (2018) suggested that a horizontal resolution of $<30 \mathrm{~km}$ is necessary to represent the air-sea interaction over the NOW. Samelson \& Barbour (2008) performed a study of a high-resolution $(6 \mathrm{~km})$ model for Nares Strait, but only for a short period of two years.

In this research article, we present a long-term study (30 years) of LLJs in Nares Strait. We used the non-hydrostatic regional climate model CCLM with 15-km resolution to simulate the entire Arctic for all winter periods 
(Nov-Apr) 1987/88 to $2016 / 17$. The results of the study are compared with ASR data for the period 2000-2016 and observations. CCLM simulations with $15-\mathrm{km}, 5-\mathrm{km}$ and $1-\mathrm{km}$ resolution were compared with observations from Heinemann's aircraft study (2018) in Nares Strait (not shown). The comparison showed that the runs with $15-\mathrm{km}$ resolution reproduce the observed structure of the LLJ realistically but slightly underestimate the maximum wind speeds compared to observations and higher resolution runs.

This article is organized as follows: after we describe the CCLM model, ASR data, observations and methods, we present a verification of the CCLM. Results of the LLJ climatology and the impact that these intensified winds have on the NOW formation are then shown, followed by a summary and conclusions.

\section{Methods and data}

\section{CCLM data}

The regional climate model CCLM (version v5.0_clml; Rockel et al. 2008) is used for the Arctic (Fig. 1) with a $15-\mathrm{km}$ horizontal resolution $(450 \times 350$ grid points $)$. CCLM is a community climate model used by around 200 members worldwide (www.clm-community.eu). The model is used in a daily forecast mode for the winters $1987 / 88$ to $2016 / 17$, with a spin-up time of six hours (each run covers 30 hours). Therefore, 30 winters (each comprising the six months of November-April) of daily simulations are available, with model outputs every one hour. In the vertical, we generally used 60 atmospheric sigma levels up to $22 \mathrm{~km}$, with 24 levels below a $2 \mathrm{~km}$ height. For the simulations of the winters
$2002 / 03$ to $2013 / 14$, the runs were performed with 42 levels (with 16 levels $<2 \mathrm{~km}$ ).

Initial and boundary data were obtained from ERAInterim reanalyses (Dee et al. 2011). For 2002-2017, we used daily sea-ice data obtained from AMSR-E and AMSR-2 for the SIC provided by the University of Bremen at a resolution of $6.25 \mathrm{~km}$ (Spreen et al. 2008). Filling up the gap between AMSR-E and AMSR-2, we used SSMIS SIC data with a resolution of $12.5 \mathrm{~km}$. For the period $1987 / 88$ to $2001 / 02$, we used OSISAF SIC data based on SSM/I (EUMETSAT Ocean and Sea Ice Satellite Application 2016), with a resolution of $12.5 \mathrm{~km}$. The seaice thickness was prescribed from PIOMAS (Zhang \& Rothrock 2003). The sea-ice thickness was merged with SIC, and areas with SIC $<70 \%$ were treated as polynyas (Gutjahr et al. 2016).

The thermodynamic two-layer sea-ice model of Schroeder et al. (2011) was included over sea ice, with the thin ice $(\leq 20 \mathrm{~cm})$ being free of snow and the sea ice thicker than $20 \mathrm{~cm}$ having a snow layer of $10 \mathrm{~cm}$. The roughness length for sea ice amounted to $1 \mathrm{~mm}$, and a modified Charnock formula (Doms et al. 2011) was applied for open-water areas. We used the implemented tile approach of Gutjahr et al. (2016) for surface energy fluxes for fractional ice cover. For the sea-ice albedo scheme, we followed Køltzow (2007).

Figure 2 shows the average $10-\mathrm{m}$ wind and the 99th percentile of the wind speed (based on hourly values) for the Arctic from CCLM simulations for the total period (November-April) 1987-88 to 2016-17. The mean wind field shows the katabatic wind over Greenland and signals of the tip jet with the highest wind speeds at southern Greenland, the northerly barrier winds at the south-east coast and gap flows in Nares Strait. The 99th
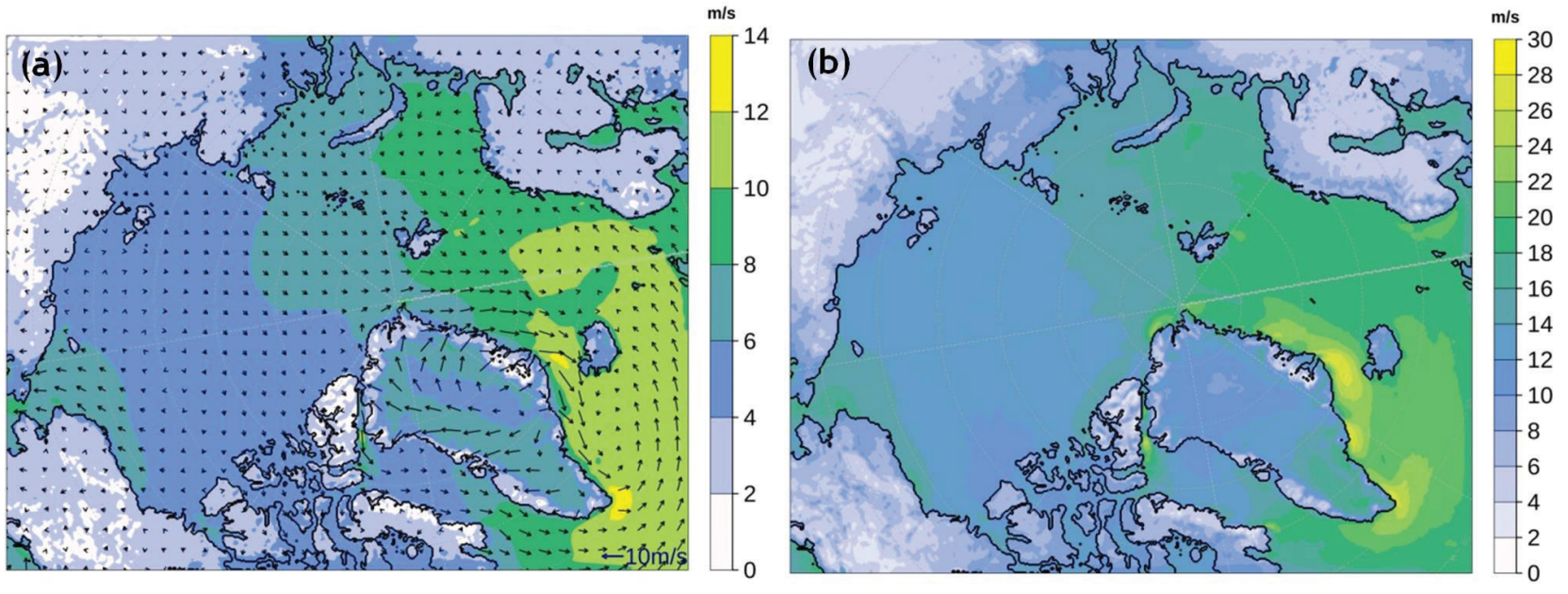

Fig. 2 (a) Mean 10-m wind (vectors every 20th grid point; scale in the lower right corner) and (b) 99th percentile for all winter months 1987/88 to 2016/17. 
percentile of the wind speed shows a clearer signal, particularly for the barrier winds and the tip jet. Wind extremes for the Arctic have been studied by Hughes $\delta$ Cassano (2015), and for CCLM simulations, studied by Gutjahr \& Heinemann (2018). They found that extreme wind speeds in the Arctic associated with mesoscale wind phenomena occur, in particular, around Greenland and increase over the ocean with an increasing horizontal model resolution. The gap flow winds in Nares Strait will be analysed in the following. The detailed topography of Nares Strait is shown in Fig. 1b, where the positions of Smith Sound, observational stations and cross-sections are marked.

\section{Additional data}

In addition to the 30-year CCLM data, we used the ASR data ASRvl at a resolution of $30 \mathrm{~km}$ (Bromwich et al. 2016) and ASRv2 at a resolution of $15 \mathrm{~km}$ (Bromwich et al. 2018; National Center for Atmospheric Research, Polar Meteorology Group, Byrd Polar and Climate Research Center) to compare with CCLM. The ASR is based on the Polar Weather Forecast Model and the High-Resolution Land Data Assimilation System. The ASR data have been optimized for the Arctic covering the area poleward of $40^{\circ} \mathrm{N}$. ASR was developed for a better understanding of the processes and consequences of a changing Arctic climate system (Bromwich et al. 2016). ASRvl spans the years 2000-2012, and ASRv2 is available for the years 2000-2016. ASR features a comprehensive sea-ice description, and thus, provides a valuable data set for comparison with the CCLM data (Kohnemann et al. 2017). Further technical information on ASRv2 is available from Bromwich et al. (2018).

In addition, we used ERA5 (Hersbach et al. 2018; Copernicus Climate Change Service [C3S] 2017) to compare with CCLM. ERA5 covers the Earth on a $30-\mathrm{km}$ grid and with 137 levels in the vertical. ERA5 was reproduced with a 4D-Var data assimilation. The data are available at sub-daily and monthly frequencies.

The observational data that we used for verification are part of the World Meteorological Organization network and observations from GC-NET (Steffen et al. 1996). Data from the following stations in the Nares Strait region were included (see Table 1, Fig. 1): Qaanaaq (42050, no. 1), Kitsissut (Carey Island, 42030, no. 2), Thule Air Base (42020, no. 3) and Alert (710823, no. 4). GC-NET data from the Humboldt Glacier, GITS and Petermann Glacier stations were used (see Fig. 1).

\section{Methods}

CCLM data with 60 levels were vertically interpolated to the 42 levels to make the analysis consistent. The lowest model level was at $20 \mathrm{~m}$. Layer distances were $40 \mathrm{~m}$ for levels 2-6 and then increase up to $200 \mathrm{~m}$ for level 13 (corresponding to $1066 \mathrm{~m}$ ). To compare CCLM with ASR, ASR is horizontally interpolated (bilinearly) to the CCLM grid. For comparison with ASR, only every third time step of the hourly CCLM data was taken, since ASR data are three hourly. To compare with the observations, we chose a bilinear interpolation of the four closest grid points to the location of each station. The 2 -m temperature was height corrected with the dry adiabatic lapse rate $\left(9.8^{\circ} \mathrm{C} / \mathrm{km}\right)$, as station height and CCLM grid point height sometimes differ on account of the $15-\mathrm{km}$ resolution.

Trends are based on the linear regression method as least squares. For the calculation of correlations, linear trends and seasonal cycle were removed.

To study the gap flow dynamics in the Smith Sound area, $\mathrm{Fr}_{m}$ was calculated (see Heinemann 2018). The $\mathrm{Fr}_{m}$ describes the dynamical behaviour of the air flow upstream of a barrier by the following equation:

$$
F r_{m}^{2}=\frac{U^{2}}{\frac{g}{\theta_{m}} \Delta \theta_{m} * h_{m}}
$$

where $U$ is the mean wind speed (and $\theta_{m}$ the mean potential temperature) in layers below the mountain height $h_{m}$ (1000 $\mathrm{m}$ for Smith Sound) and $\Delta \theta_{m}$ is the bulk difference of the potential temperature at $h_{m}$ and the surface. $\mathrm{Fr}_{m}$ is calculated for a grid point (longitude -70.33 , latitude 79.48) north of Smith Sound in the Kane Basin (see Fig. 1).

Table 1 Synoptic stations in the area of Nares Strait used for the comparison with the periods of available data for the winter periods $1987 / 88$ to $2016 / 17$

\begin{tabular}{lllccc}
\hline & Station no. and name & WMO & Long/lat & Station height (m) & CCLM height (m) \\
\hline 1 & Mittarfik Qaanaaq & 042050 & $-69.383 / 77.483$ & 16 & 125 \\
2 & Kitsissut (Carey Oeer) & 042030 & $-73.000 / 76.633$ & 11 & 0 \\
3 & Thule Air Base & 042020 & $-68.703 / 76.531$ & 76 & $2005-2017$ \\
4 & Alert & 710823 & $-62.281 / 82.518$ & 30 & $1987-2017$ \\
\hline
\end{tabular}

aFor station locations, see Fig. 1. ' World Meteorological Organization. 


\section{Results: validation and comparison}

CCLM simulations have already been compared with observations in a number of studies but not specifically for the Nares Strait region. A validation of CCLM for the 2-m temperature in the Arctic has been performed by Kohnemann et al. (2017) for the winter periods (November-April) 2002/03 to 2011/12: they showed that the agreement with observations of coastal stations was accurate with a bias between 0 and $2{ }^{\circ} \mathrm{C}$ for the Siberian coast and little higher for the region of Greenland and the Canadian Arctic Archipelago (up to $\pm 4{ }^{\circ} \mathrm{C}$ ). The differences of the 2 -m temperature between CCLM and ASRvl were minor over the sea ice $\left( \pm 1{ }^{\circ} \mathrm{C}\right)$ and ocean areas for the winter periods 2002/03 to 2011/12 (Kohnemann et al. 2017). Gutjahr \& Heinemann (2018) compared CCLM with ERA-Interim, ASRv1, ASRv2 and a satellite-based data set of the 10-m wind for the winter periods 2000/01-2011/12 (i.e., the period when all data sets overlap). They concluded that a $15-\mathrm{km}$ model resolution is required to sufficiently capture extreme wind events in the Arctic, but physical parameterizations of surface fluxes and of turbulence affect the simulation of extreme winds as well. Gutjahr et al. (2016) compared CCLM results to automatic weather stations over fast ice in the Laptev Sea for April 2008, and found that CCLM was able to reproduce the near-surface temperature, wind speed and net radiation. A verification study of CCLM over thick sea ice in late winter by Heinemann et al. (2021) showed an excellent agreement with measurements for the near-surface variables and the structure of the troposphere. Zentek $\delta$ Heinemann (2020) performed an extensive verification of CCLM for the Antarctic for the period 2002-2016 using radio soundings, data from Antarctic stations and AWS over the ice sheet and sea ice, as well as lidar wind profiles. A warm bias of the model was found for the near-surface temperature over the Antarctic plateau for extremely stable conditions during winter, while the wind speed bias was small. Overall, CCLM showed a good representation of temperature and wind. Heinemann (2020) evaluated CCLM simulations for the katabatic wind over the Greenland ice sheet and found a small negative bias for the $10-\mathrm{m}$ wind $(-0.5 \mathrm{~m} / \mathrm{s})$. A comparison of CCLM (together with five other state-ofthe-art regional climate models) for the Arctic summer using ship measurements with a focus on surface fluxes and clouds was shown by Sedlar et al. (2020). CCLM was found to overestimate the sensible heat flux in the stable regime and to slightly underestimates the fluxes in the convective regime (differences in the range of 20 $\left.\mathrm{W} / \mathrm{m}^{2}\right)$. Overall, CCLM performed well compared with observations and the other regional climate models.
Figure 3 shows a comparison of CCLM (15 km), ASRvl $(30 \mathrm{~km}), \operatorname{ASRv} 2(15 \mathrm{~km})$ and ERA5 $(30 \mathrm{~km})$ for wind speed and MSLP in Nares Strait for the overlapping data sets in the period of all winter months 2002/03 to $2011 / 12$. ASRvl with a 30-km horizontal resolution was not able to resolve the Nares Strait channel properly as the Kennedy Channel was partially land-covered (Fig. 3c). The along-strait wind patterns were diffuse, and the wind maximum at Smith Sound was weak. ASRv2 and CCLM (both with $15-\mathrm{km}$ resolution), and to some extent also ERA5, were able to resolve the topographic structures. The vector mean wind speed had a maximum of about $14 \mathrm{~m} \mathrm{~s}^{-1}$ in the Smith Sound area for ASR2 and CCLM simulations. The flow pattern was nearly parallel to the strait, with a southward flow across the pressure gradient from Lincoln Sea towards Baffin Bay. Compared with ASRv2, much weaker katabatic winds over the Greenland ice sheet were simulated by CCLM. ERA5 showed a weaker wind maximum of $8 \mathrm{~m} \mathrm{~s}^{-1}$ in the Smith Sound area. Samelson \& Barbour (2008) presented results of a simulation with $6-\mathrm{km}$ resolution for Smith Sound, but only for ocean grid points. The structure of the low-level flow pattern of CCLM agrees strongly with their results (not shown). The simulated maximum of vector mean 10-m wind at Smith Sound was well defined and located where Samelson \& Barbour (2008) placed it, but it is more intense in the results of this study. Their maximum speed reached $10 \mathrm{~m} \mathrm{~s}^{-1}$, whereas CCLM speeds were up to $14 \mathrm{~m} \mathrm{~s}^{-1}$.

In order to verify the CCLM simulations over the ice sheet, a comparison was made with data obtained from three GC-NET stations, which are in the areas of interest in northern Greenland (see Fig. 1). We used data for the period 1995-2008. The GITS has data for the period 1995-2008, the Humboldt Glacier station for the period 1995-2007 and the Petermann Glacier station for the period 2002-03. As the wind measurements are made at 2-m height, the CCLM wind speed available at $10 \mathrm{~m}$ was computed for 2 -m height using a logarithmic wind profile. This comparison showed that the wind speed bias (CCLM minus observations) was small ( 1.58 to $-0.29 \mathrm{~m} \mathrm{~s}^{-1}$ ), and the RMSE ranges from 1.24 to $2.98 \mathrm{~m} \mathrm{~s}^{-1}$ (daily means). The difference in wind direction was small for the Humboldt station $\left(4^{\circ}\right)$, higher for GITS with $12^{\circ}$ and largest $\left(52^{\circ}\right)$ for the Petermann Glacier station. Data from the Petermann Glacier station cover only one winter, and local topography effects are a likely reason for this large difference. Overall, these results show that the wind over the ice sheet was simulated realistically by CCLM.

A comparison with the findings of Moore $\&$ Våge (2018) for January-April 2016 and operational ECMWF data with $9-\mathrm{km}$ resolution reveals that the CCLM wind 

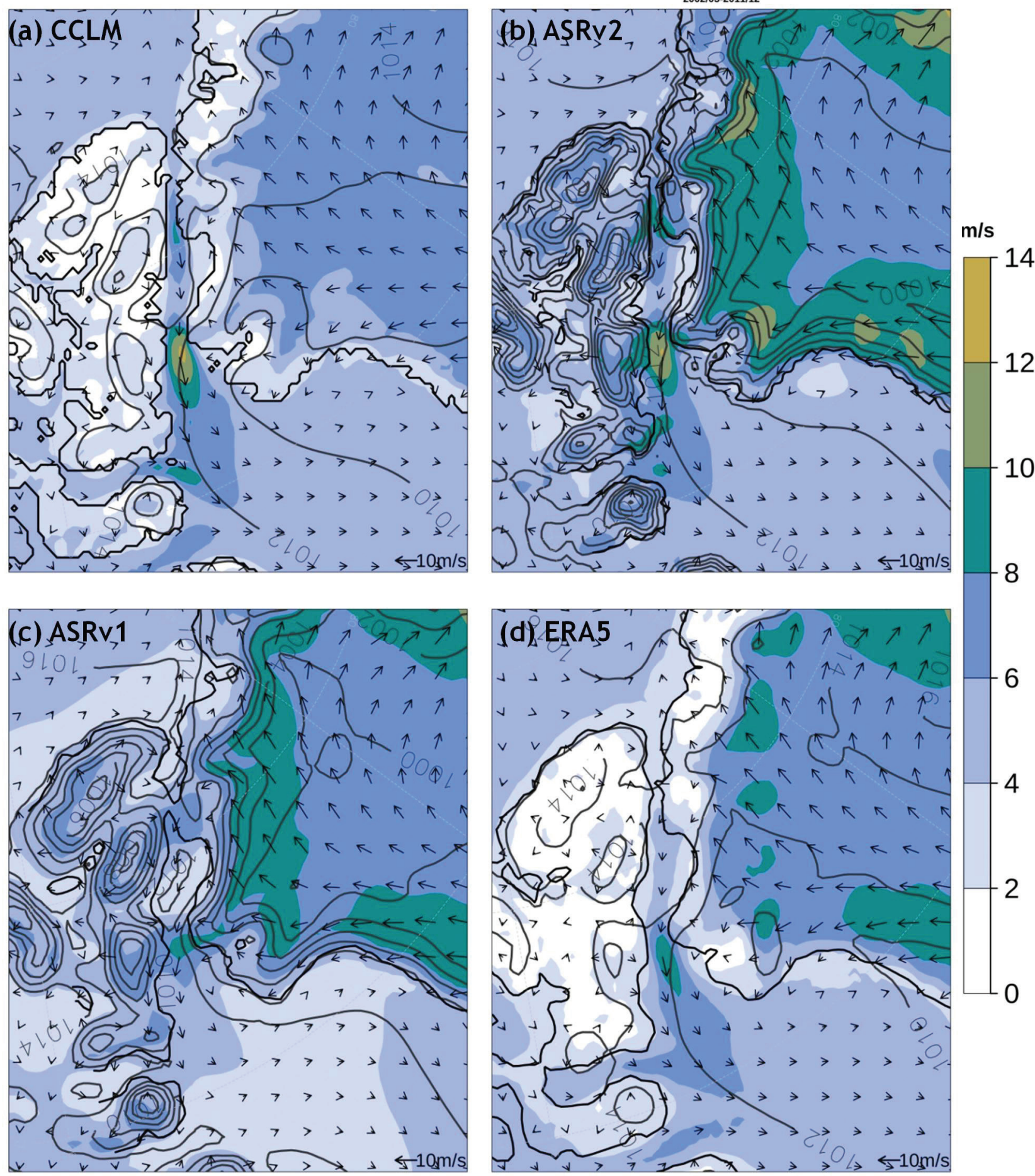

Fig. 3 Mean 10-m wind vector (scale in the lower right corner) with magnitude and MSLP (contours every $2 \mathrm{hPa}$ ) of (a) CCLM, (b) ASRv2, (c) ASRv1 and (d) ERA5 for all winter months 2002/03 to 2011/12. Vectors are shown for every sixth grid point of the CCLM grid.

and MSLP fields are very similar to ECMWF data (not shown). However, the 2-m air temperature displays larger differences, which is likely due to the different seaice data inputs of the simulations.
Table 2 presents the statistical comparison between four meteorological stations and the equivalent grid points of CCLM in the area of Nares Strait for all winter periods. MSLP biases range between -0.2 and $-1.1 \mathrm{hPa}$. 
Table 2 Statistical comparison of daily means between observations and CCLM for all winter periods 1987/88 to $2016 / 17$.

\begin{tabular}{|c|c|c|c|c|c|c|c|c|c|c|c|c|c|c|c|c|}
\hline & \multirow{2}{*}{$\begin{array}{l}\text { Station no. } \\
\text { and name }\end{array}$} & \multicolumn{5}{|c|}{ MSLP (hPa) } & \multicolumn{5}{|c|}{$\mathrm{T} 2 \mathrm{~m}^{\mathrm{a}}\left({ }^{\circ} \mathrm{C}\right)$} & \multicolumn{5}{|c|}{ Wind speed $\left(10 \mathrm{~m} \mathrm{~s}^{-1}\right)$} \\
\hline & & $\begin{array}{l}\mathrm{OBS}^{\mathrm{b}} \\
\text { mean }\end{array}$ & $\begin{array}{l}\text { CCLM } \\
\text { mean }\end{array}$ & $\mathrm{BIAS}^{\mathrm{c}}$ & RMSE & $r^{d}$ & $\begin{array}{l}\mathrm{OBS}^{\mathrm{b}} \\
\text { mean }\end{array}$ & $\begin{array}{l}\text { CCLM } \\
\text { mean }\end{array}$ & $\mathrm{BIAS}^{\mathrm{c}}$ & RMSE & $r^{d}$ & $\begin{array}{l}\mathrm{OBS}^{\mathrm{b}} \\
\text { mean }\end{array}$ & $\begin{array}{l}\text { CCLM } \\
\text { mean }\end{array}$ & $\mathrm{BIAS}^{\mathrm{c}}$ & RMSE & $r^{\mathrm{d}}$ \\
\hline 1 & Mittarfik & 1010.2 & 1010.5 & 0.2 & 1.1 & 0.96 & -18.4 & -24.1 & -5.7 & 7.3 & 0.63 & 1.8 & 2.7 & 0.9 & 2.2 & 0.34 \\
\hline 2 & Kitsissut & 1009.5 & 1010.6 & 1.1 & 1.7 & 0.95 & -16.5 & -19.6 & -3.1 & 5.6 & 0.65 & 5.9 & 6.3 & 0.4 & 2.2 & 0.69 \\
\hline 4 & Alert & 1015.9 & 1016.3 & 0.4 & 1.5 & 0.95 & -28.9 & -31.3 & -2.5 & 4.3 & 0.68 & 2.3 & 3.0 & 0.8 & 2.3 & 0.57 \\
\hline
\end{tabular}

a2-m temperature. ${ }^{b}$ Observations. ${ }^{c}$ Mean difference. ${ }^{\mathrm{d} A}$ Anomaly correlation. ${ }^{\mathrm{e} T h u l e ~ A i r ~ B a s e . ~}$
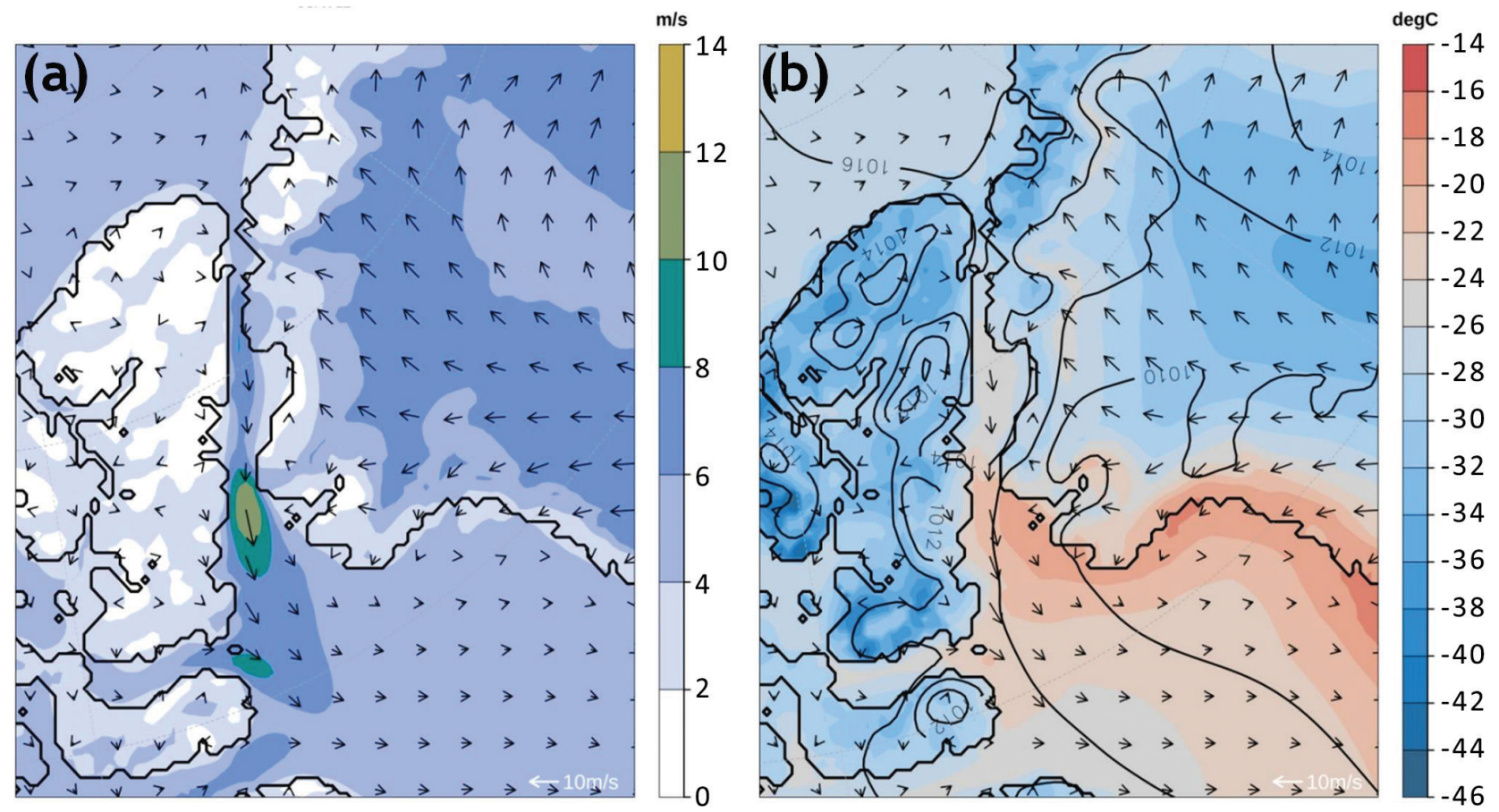

Fig. 4 Mean 10-m wind vector (vectors every sixth grid point, scale in the lower right corner) with (a) magnitude and (b) MSLP (contours every 2 hPa) and mean 2-m temperature for November-April 1987/88 to 2016/17.

RMSEs range between 1.0 and $1.8 \mathrm{hPa}$. For 2 -m temperature, the bias and RMSE are relatively large. RMSEs for wind speeds are between 2.3 and 2.5. With the exception of Kitsissut (on a small island), the stations are in a topographically complex terrain and may be influenced by local effects. Anomaly correlations were high for MSLP (0.95-0.96), between 0.63 and 0.76 for the 2-m temperature and 0.34-0.69 for wind speed. The wind speed correlation was largest for Kitsissut, and local effects can be considered to be responsible for low correlations for the wind speed at the other stations.

\section{Results: orographically forced winds in Nares Strait}

\section{Climatology of wintertime LLJs}

The near-surface fields from CCLM winter (Nov-Apr) $1987 / 88$ to $2016 / 17$ showed a climatological picture of the mean state in Nares Strait (Fig. 4). The pressure field decreased from $1016 \mathrm{hPa}$ in Lincoln Sea down to $1010 \mathrm{hPa}$ in Baffin Bay, which was associated with a low over Baffin Bay. Because of the steep topography on both sides of the channel, the isobars were oblique to the along-strait 
direction, with local enhancement and direction changing near the region of Smith Sound. In Nares Strait, the southward flow was parallel to the pressure gradient, that is, it was strongly ageostrophic, while it became nearly geostrophic south of Smith Sound. In accordance with the gap flow theory, the stably stratified wind flow was forced through the narrowest gaps in Kennedy Channel and Smith Sound, leading to wind speed maxima. Maximum wind areas occurred near and downstream, not within, the narrowest points, as might be expected, but instead in the gap exit regions. The $10-\mathrm{m}$ wind maximum associated with Kennedy Channel (6-8 $\left.\mathrm{m} \mathrm{s}^{-1}\right)$ was much weaker than that of Smith Sound (up to $12 \mathrm{~m} \mathrm{~s}^{-1}$ ). For Smith Sound, the acceleration south of the gap was also caused by the geostrophic flow associated with the cyclone. The 2-m air temperature increases from north to south throughout the channel (Lincoln Sea about $-28^{\circ} \mathrm{C}$, Smith Sound area up to $-18^{\circ} \mathrm{C}$ ). The large temperature gradient across Smith Sound was associated with the typical ice bridge and the location of the NOW (Preusser et al. 2015). The possible contribution of the gap flow dynamics to the temperature structure is discussed below.

The strength of a gap flow is strongly dependent on the strength of the pressure gradient between the gap entrance and exit region. Figure 5 shows the daily means of the pressure difference between the CCLM grid points, Alert and the exit region of Smith Sound and the simulated 10-m wind speed at Smith Sound. An increasing positive pressure difference between Alert and Smith Sound resulted in higher wind speeds at Smith Sound itself. This typical southward flow pattern due to pressure in Nares Strait was observed in $76 \%$ of all winter days, $1987 / 88$ to $2016 / 17$ (Fig. 5). The pressure differences were caused by the overall Arctic pressure situation. A quarter of the days show negative pressure differences, but the magnitude of the difference and the associated wind speed were much lower than for the positive pressure differences. Averaged over the single months, only six out of 180 months showed a negative pressure difference.

Figure 6 shows the ver tical cross-sections of mean potential temperature and wind speed from Kennedy Channel through Nares Strait to Baffin Bay (line A-B in Fig. 1) for different winter months. The height of the cross-section corresponds to the that of the channelling topography (around $1000 \mathrm{~m}$ ). Stable conditions with a potential temperature increase of around $10^{\circ} \mathrm{C} \mathrm{km}^{-1}$ were observed in all months. Thus, there were favourable conditions for a gap flow, as the wind flow was forced through the gap. The cross-section of the mean wind speed shows two LLJs related to Kennedy Channel and Smith Sound, respectively (Fig. 6). The strongest winds with up to almost $18 \mathrm{~m} \mathrm{~s}^{-1}$ were simulated at a height of 100-250 m in the gap exit region of Smith Sound. The strongest

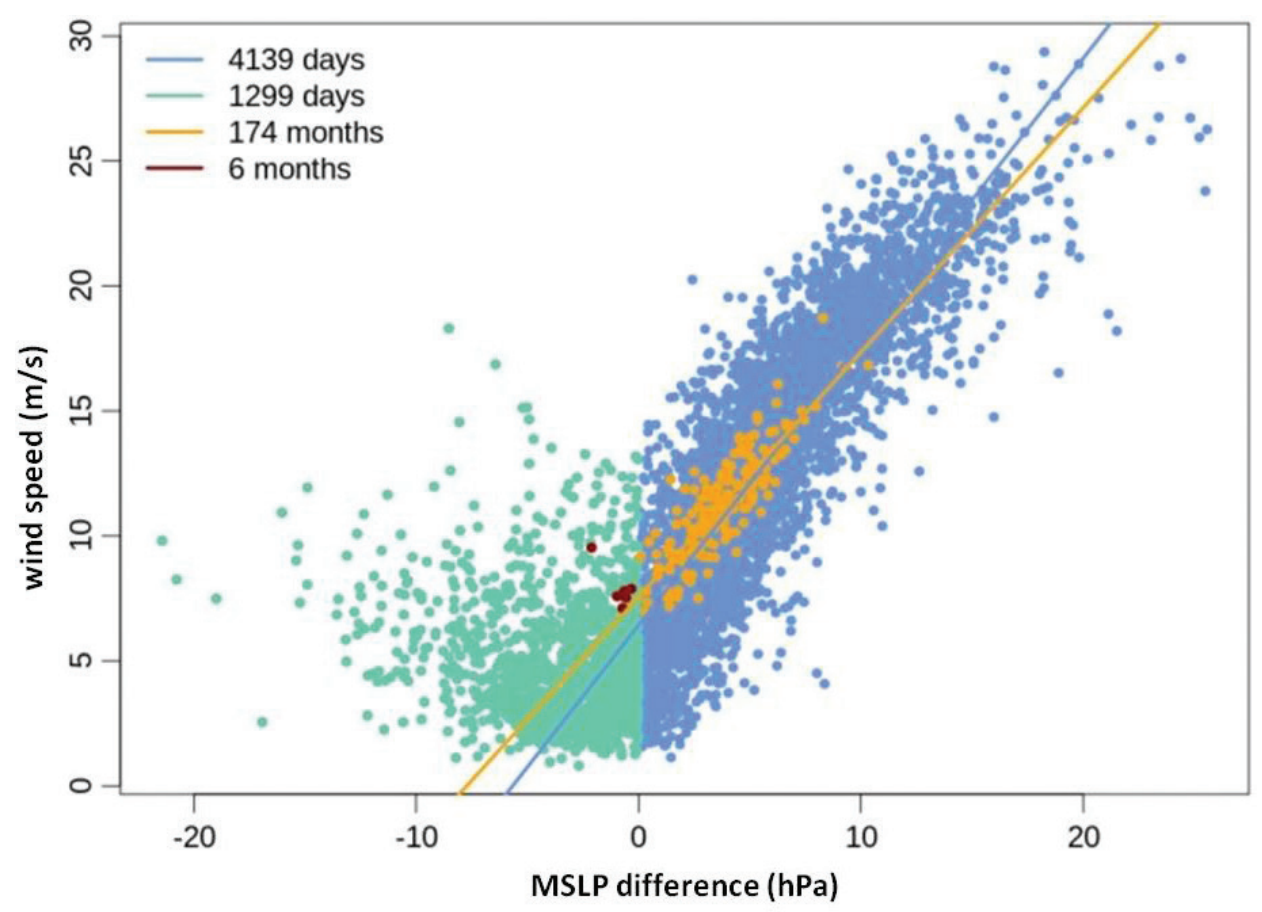

Fig. 5 MSLP difference between CCLM grid points close to Alert (-62.28 longitude, 82.52 latitude) and Smith Sound (-74.80 longitude, 77.80 latitude) versus 10-m wind speed at Smith Sound on a daily (blue, green) and monthly (orange, red) basis for 1987/88 to $2016 / 17$. 


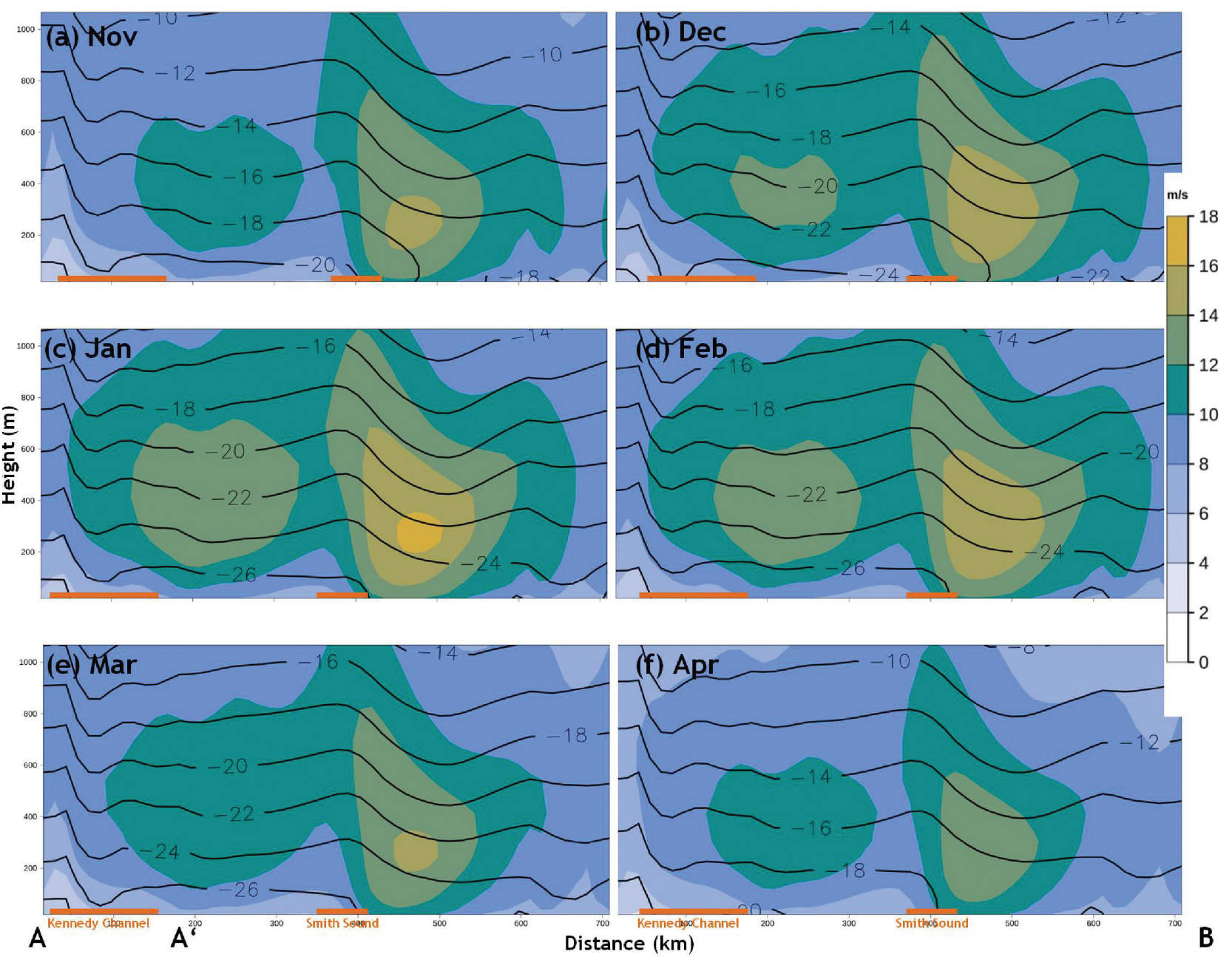

Fig. 6 Vertical cross-section of mean wind speed ( $\mathrm{m} \mathrm{s}^{-1}$ ) along the Nares Strait (line A-B; see Fig. 1) for individual months 1987/88 to 2016/17. Black contours are potential temperature $\left({ }^{\circ} \mathrm{C}\right)$. A' location for comparison with Fig. 8.

mean wind speeds were reported during January. Towards the autumn and spring months (November and April), the mean wind speed dropped down to $13-14 \mathrm{~m} \mathrm{~s}^{-1}$. For the Smith Sound LLJ, a clear relation of the LLJ to a gravity wave was observed in the potential temperature field, which also led to a distinct warming of the lower $1000 \mathrm{~m}$ south of the gap.

Figure 7 shows the cross-section perpendicular to the axis of Smith Sound (line E-F in Fig. 1) for January, when the LLJ was strongest. The cross-section is located in the exit region of the Smith Sound gap. The jet core with more than $16 \mathrm{~m} \mathrm{~s}^{-1}$ extended between 200 and $400 \mathrm{~m}$ height, and had a width of about $30 \mathrm{~km}$. The jet lies not in the centre of Smith Sound but closer to the coast of Greenland. The temperature structure shows the jet as a warm anomaly, which is in accordance with the wave signature illustrated in Figs. 6 and 8.
Figure 8a shows the vertical wind cross-section through the centre of Smith Sound (line A'-B in Fig. 1) for January. It indicates a slight descent and warming associated with the wave in the along-gap flow direction. The descending air flow value of only $4 \mathrm{~cm} \mathrm{~s}^{-1}$ is a result of the model resolution and the long-term averaging. Shifting the cross-section by two grid points towards Greenland (line C-D in Fig. 1) demonstrates the relation of the wave to the topography (Fig. 8b): upstream of the barrier, the flow is partly blocked and is channelled through Smith Sound, but it also flows over the mountains resulting in a high-amplitude wave.

\section{Jet variability $1987 / 88$ to $2016 / 17$}

The LLJ climatology shows a wind structure that fulfils the common definition of an LLJ. Although there are 


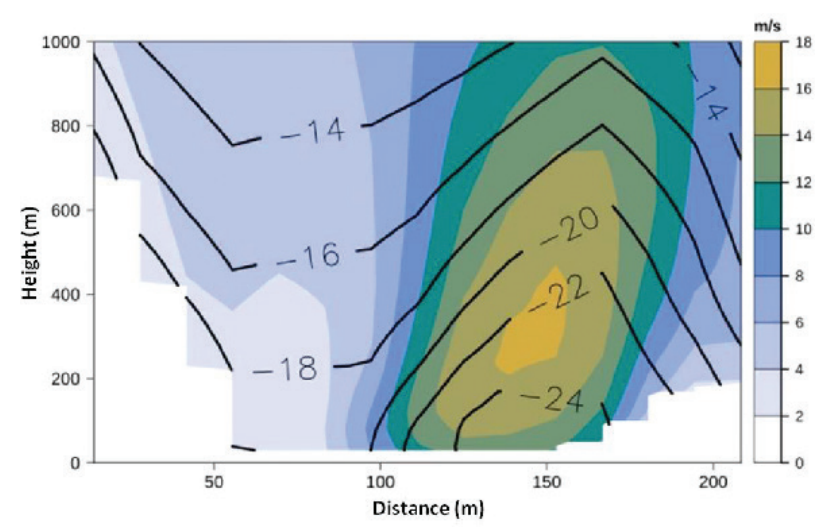

Fig. 7 Vertical cross-section of mean wind speed $\left(\mathrm{m} \mathrm{s}^{-1}\right)$ for the cross-section through Smith Sound (line E-F, see Fig. 1) for Jan 19882017. The cross-section is from Canada (left) to Greenland. White area represents land.

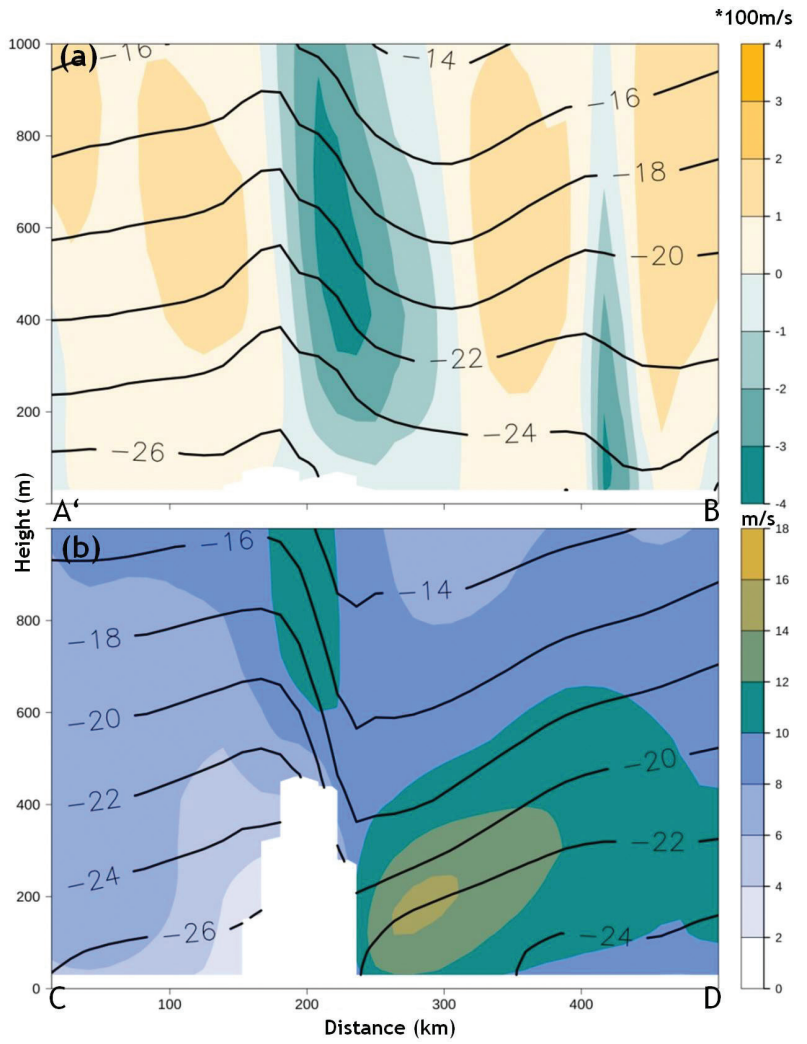

Fig. 8 (a) Vertical cross-section of the vertical wind $\left(w^{*} 100\right)$ and potential temperature (isolines every $2^{\circ} \mathrm{C}$ ) along the Nares Strait (line $A^{\prime}-B$; see Fig. 1) for Jan 1988-2017. (b) Vertical cross-section of mean wind speed $\left(\mathrm{m} \mathrm{s}^{-1}\right)$ for the cross-section parallel to line A'-B (line C-D; see Fig. 1) for January 1988-2017. various definitions in the literature, all require a wind speed maximum in the lower troposphere. The LLJ is detected as the vertical level with the maximum wind speed of at least $2 \mathrm{~m} \mathrm{~s}^{-1}$ greater than any level below and above (following Andreas et al. 2000; Jakobson et al. 2013). We only considered LLJs $<1000 \mathrm{~m}$ within a square area of $11 \times 26$ grid points around Smith Sound. For analysing LLJ statistics, we chose the position and the height of the daily maximum wind speed. The frequency distribution of LLJ speeds ranged from 5 to $48 \mathrm{~m} \mathrm{~s}^{-1}$ (Fig. 9a). The majority of LLJs (93\%) had wind speeds $>10 \mathrm{~m} \mathrm{~s}^{-1}$; $13 \%$ exceeded $30 \mathrm{~m} \mathrm{~s}^{-1}$ as daily mean. As about $20 \%$ of the synoptic situations were associated with a negative pressure difference along Nares Strait, we plotted the LLJs with northerly winds separately. The highest wind speeds were associated almost exclusively with northerly winds. The maximum frequency of LLJ speeds was 15-20 $\mathrm{m} \mathrm{s}^{-1}$ for all winds and was $20-25 \mathrm{~m} \mathrm{~s}^{-1}$ for the northerly winds. The vertical distribution of LLJ heights is also shown in Fig. 9b. The frequency of LLJs at different heights was calculated as a density, which is the frequency normalized with the thickness of the model layers. The distribution is, therefore, comparable for the different model layers, and the area of each bar is proportional to the LLJ frequency. The height distribution for all LLJs and only the northerly LLJs is almost the same. The maximum density of LLJs was observed between 200 and $250 \mathrm{~m}$.

Figure 10 shows the maximum wind speed distributions for northerly winds as a function of $\mathrm{Fr}_{m}$. With the $\mathrm{Fr}_{m^{\prime}}$, we can differentiate the flow in case of blocking or describe different flow regimes of gap flows (Gaberšek \& Durran 2004). $\mathrm{Fr}_{m}$ was calculated for a vertical profile in Kane Basin north of the Smith Sound entrance region (see Fig. 1). As expected, increases in $\mathrm{Fr}_{m}$ were related to increasing LLJ speeds. The $F r_{m}$ increased linearly with the increasing upstream flow speed, which reflected a larger pressure gradient in Nares Strait. A larger pressure gradient is related to a higher wind speed in Smith Sound (see Fig. 5). Figure 11 shows that the larger pressure gradient for larger $\mathrm{Fr}_{m}$ values resulted mainly from a deeper low over Melville Bay. A clear separation of LLJ regimes was observed: $F r_{m} \leq 0.3$ was related to a frequency maximum at 10-12 $\mathrm{m} \mathrm{s}^{-1}$, and $\mathrm{Fr}_{m}$ values in the range of 0.6-0.9 were associated with a frequency maximum at around $30 \mathrm{~m} \mathrm{~s}^{-1}$. The vertical distribution of LLJ heights for different $\mathrm{Fr}_{m}$ values increased in height with increasing $\mathrm{Fr}_{m}$. Most LLJs were observed between 200 and $400 \mathrm{~m}$ for $F r_{m}<1$. The distribution for $\mathrm{Fr}_{m}>1.2$ ranged from 250 to $700 \mathrm{~m}$ with no clearly preferred level. Both the wind speed and the static stability used for the calculation of $\mathrm{Fr}_{m}$ showed a large range of values. 

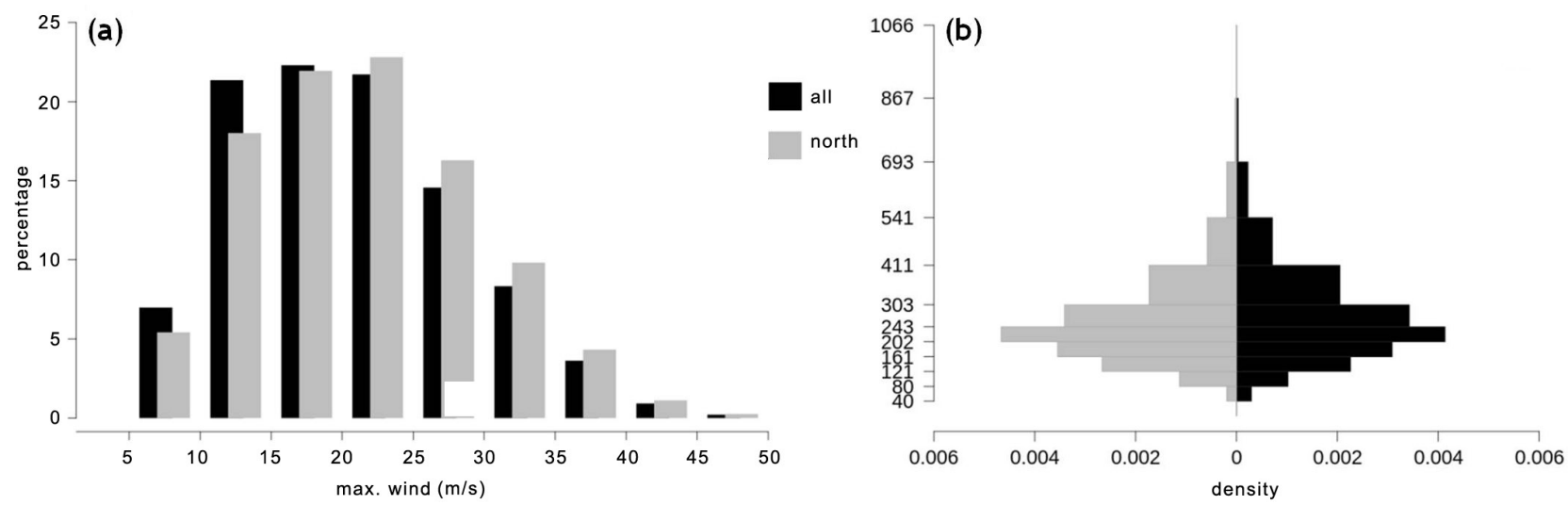

Fig. 9 (a) LLJ wind speed distribution (relative frequency in percent) and (b) LLJ density histogram for the model-level heights. Both are around Smith Sound for the daily means of $1987 / 88$ to 2016/17 for all directions (black) and for only northerly directions (grey). The density is the frequency normalized with the layer thickness.
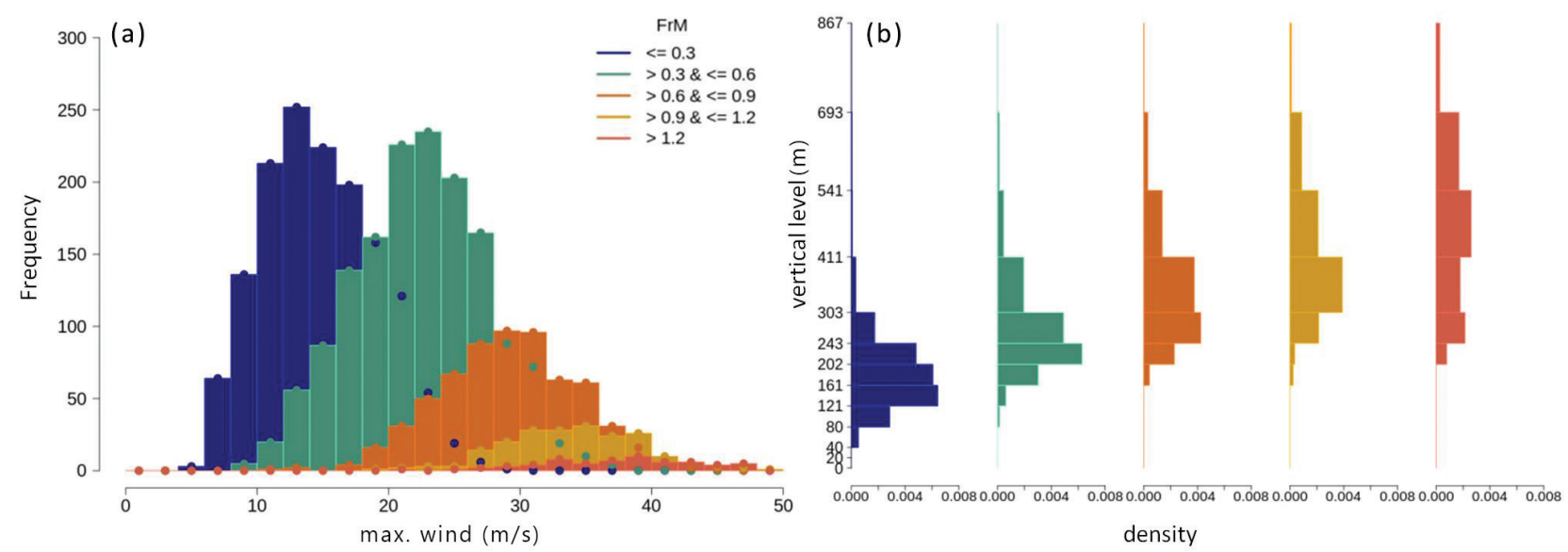

Fig. 10 (a) Different $F r_{m}$ with related LLJ wind speed distribution and (b) LL density histogram for the model level heights differentiated by $F r_{m}$. Both are around Smith Sound for all daily means $1987 / 88$ to 2016/17. $F r_{m}$ is calculated for a grid point upstream of the gap in Kane Basin (see Fig. 1). The density is the frequency normalized with the layer thickness.

Figure 11 shows the fields of the mean $10 \mathrm{~m}$ wind speed for the three $F r_{m}$ classes: $\leq 0.3,0.6-0.9$ and $>1.2$. For small $\mathrm{Fr}_{m}$ values, the jet was only present in Smith Sound, and the pressure gradient was relatively weak. For higher $\mathrm{Fr}_{m}$ values, the low over Melville Bay was stronger, and there were much larger pressure gradients at Smith Sound and southward. The gap flow at the exit of Kennedy Channel was also present.

The wind trend for the period $1987 / 88$ to $2016 / 17$ in Nares Strait was variable for different months (not shown). November and February showed a significantly negative trend of -0.6 to $-1.2 \mathrm{~m} \mathrm{~s}^{-1}$ per decade for the Smith Sound region. In December, January and April, there was almost no trend. March showed a positive trend of $1.4 \mathrm{~m} \mathrm{~s}^{-1}$ per decade.

\section{Strong wind events}

Figure 12 presents the number of strong wind events for each winter in the Smith Sound exit region (-74.8 longitude, 77.8 latitude, as in Fig. 5). A strong wind event is defined as a daily mean of $10-\mathrm{m}$ winds $\geq 20 \mathrm{~m} \mathrm{~s}^{-1}$. Strong wind events were observed for 15.2 days per winter $(8 \%)$, on average. However, there was a large interannual variability. The minimum number of events reported was six for the winters of 1988/89, 1994/95 and 2016/17. The maximum number of events (42) was reported in winter months 2002/03. Figure 12b shows the statistics of strong wind events for different months. The median and the 75th and 90th percentiles were highest in December and January, whereas March and April had the lowest 

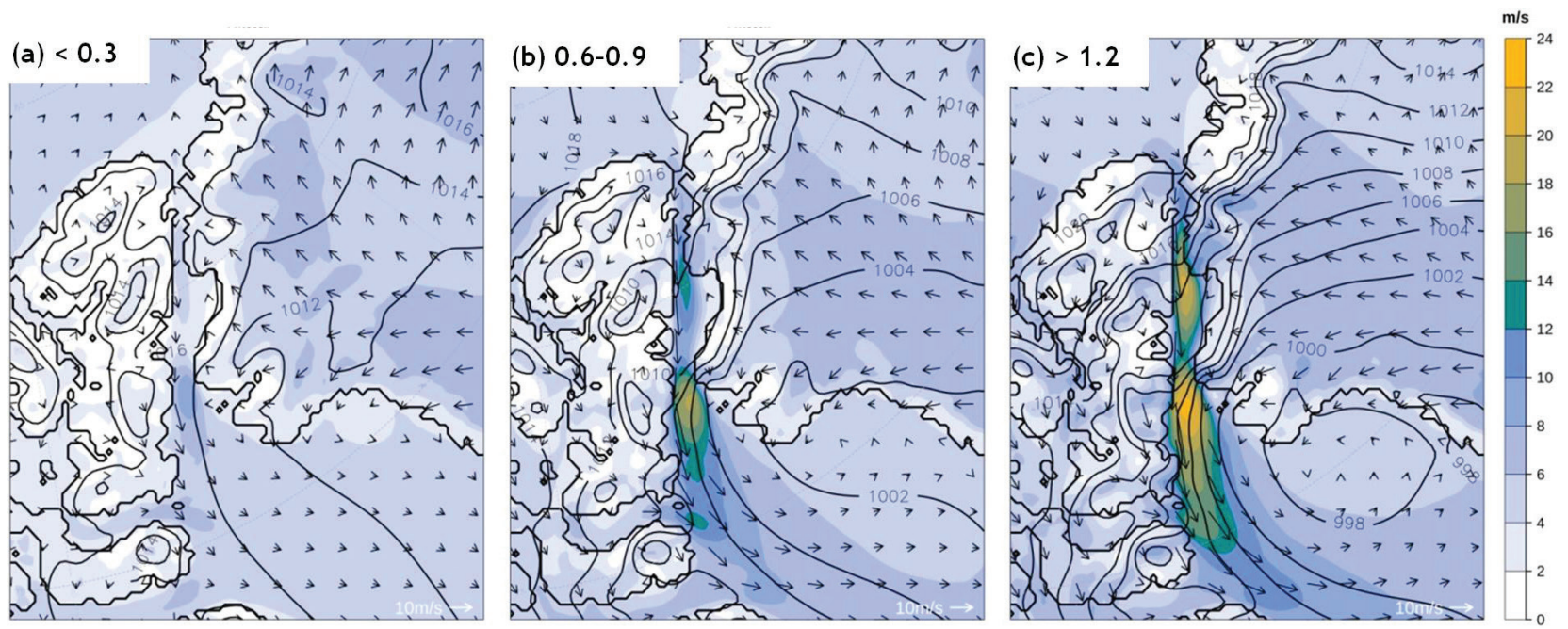

Fig. 11 Mean wind (vectors every sixth grid point) and MSLP for all days of the $F r_{m}$ classes: (a) $<0.3$, (b) $0.6-0.9$ and (c) $>1.2$.
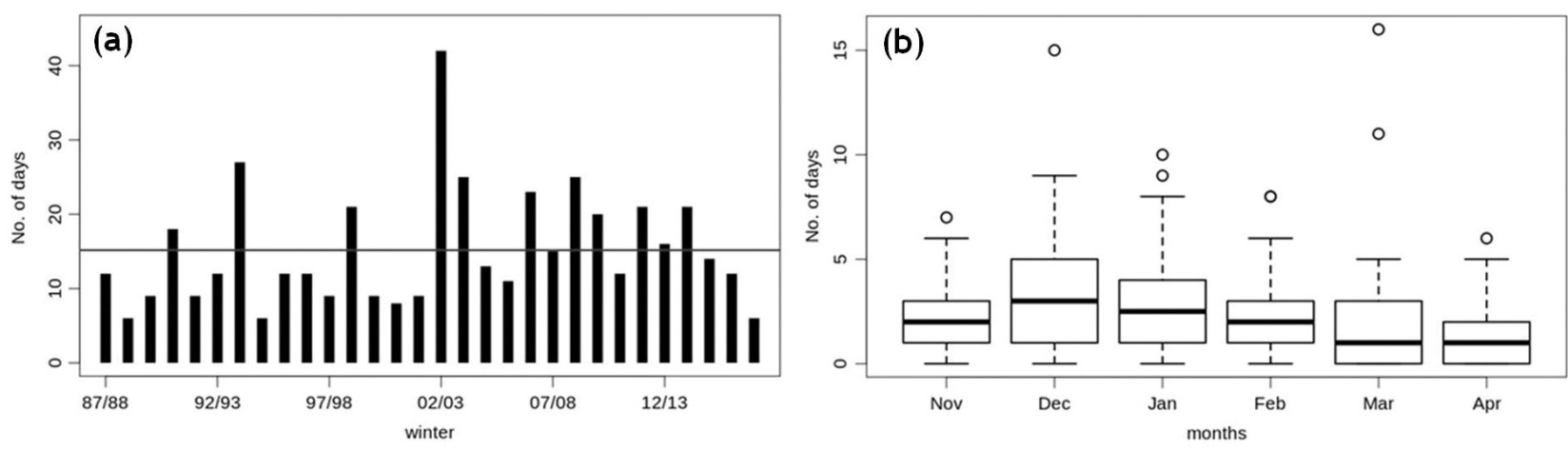

Fig. 12 (a) Frequency of all days with a 10-m wind speed $>20 \mathrm{~m} \mathrm{~s}^{-1}$ for all winters and (b) box-whisker plots for winter months for 1987/88 to 2016/17. The grey line shows the overall mean. Boxplots show the median, the 25/75th and the 5/95th percentiles; circles mark the maximum values.

median, but the highest number of events (16) was reported in March 2003, followed by 15 events in December 1998 and 11 events in March 2009.

\section{NOW interconnection}

The CCLM data can also be used to show the relation between wind and the NOW (Fig. 13a). The correlation between daily means of the $10-\mathrm{m}$ wind speed and the SIC on the same day was as much as -0.8 for the Smith Sound exit region. For a lag of one day, the correlation was smaller (maximum correlation only -0.38 ; not shown). The winds out of Smith Sound are the main cause for the formation of the NOW (Yao \& Tang 2003). As the gap flow intensifies the wind, it contributes to the formation process. For calculating the correlation, the seasonal influence was removed by subtracting the particular monthly mean of all years from the associated daily means.
The effect on the ocean-atmosphere interaction can be demonstrated by the sensible heat flux (Fig. 13b). Downstream from Smith Sound, the sensible heat flux to the atmosphere is largest and had absolute values of 100-200 W m-2 as means for December-February 1987/88 to $2016 / 17$ (note that the sign convention in CCLM is negative for fluxes directed into the atmosphere). The mean latent heat flux was approximately half as large as the mean sensible heat flux. This is similar to the results of simulations with 9-km resolution by Moore \& Våge (2018), who found an average of $160 \mathrm{~W} \mathrm{~m}^{-2}$ for the sum of sensible heat and latent heat fluxes in the same area for JanuaryApril 2016. The 95th percentile of the sum of turbulent fluxes of Moore \& Våge (2018) exceeds $1300 \mathrm{~W} \mathrm{~m}^{-2}$. In $1-5 \%$ of the cases in this study, absolute values of the sensible heat flux of more than $580-800 \mathrm{~W} \mathrm{~m}^{-2}$ were exceeded. This indicates that the extreme ocean-atmosphere interaction processes that occur with the opening of the sea-ice area are due to the wind. 

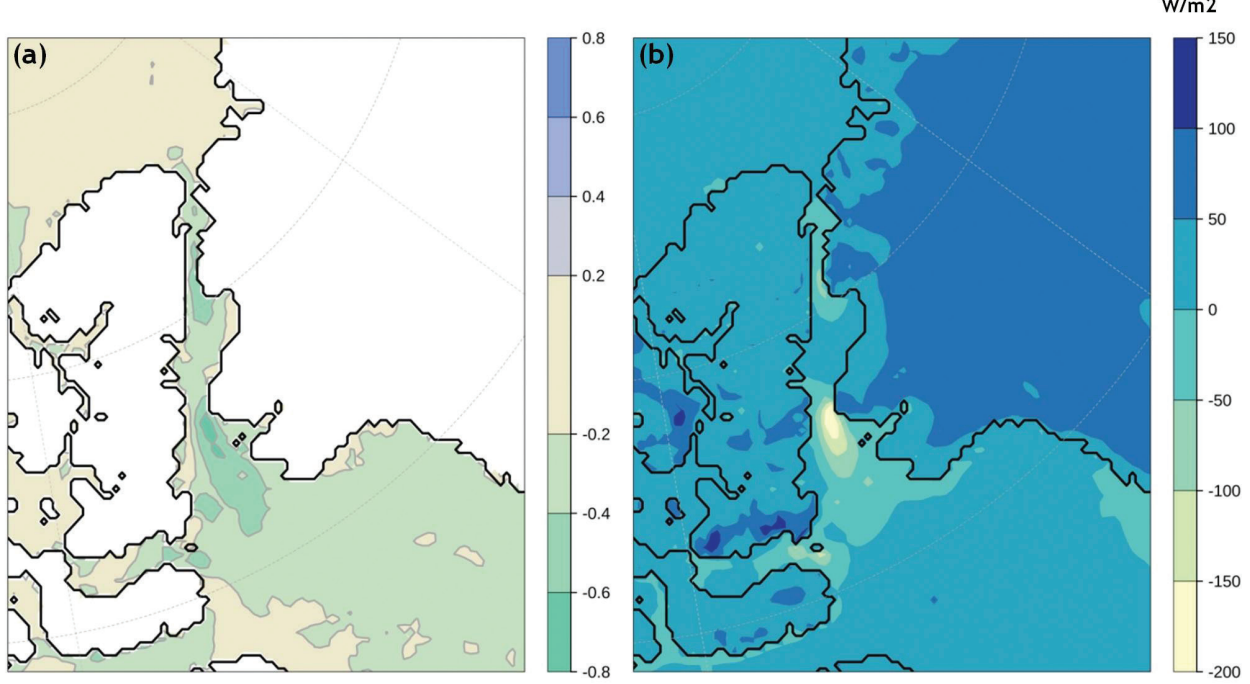

Fig. 13 (a) Correlation of CCLM daily mean wind speed and SIC for December-February 1987/88 to 2016/17. (b) Mean sensible heat flux (W m²) for December-February $1987 / 88$ to 2016/17. Negative flux values represent fluxes directed to the atmosphere.

\section{Summary}

We presented regional climate model simulations using CCLM at a resolution of $15 \mathrm{~km}$, with a focus on LLJs in Nares Strait. The climatological mean for the 30 winters of 1987/88 to 2016/17 shows a well-developed LLJ structure for Smith Sound, with a maximum mean 10-m wind speed of about $12 \mathrm{~m} \mathrm{~s}^{-1}$. For Kennedy Channel, the mean 10-m wind speed maximum is much weaker $\left(\sim 8 \mathrm{~m} \mathrm{~s}^{-1}\right)$. The LLJs are associated with gap flows in the narrowest parts of Kennedy Channel and Smith Sound under stably stratified conditions. The strength of the gap flow depends on the pressure gradient between the gap entrance and exit, where a mean pressure difference between Lincoln Sea and Baffin Bay of about $6 \mathrm{hPa}$ is found. For Smith Sound, there is a clear relation of the LLJ with a terrain-generated gravity wave.

The analysis of the jet core statistics shows that the highest frequency of LLJs was observed at a height of $250 \mathrm{~m}$. The daily mean LLJ speed distribution shows a maximum of $15-20 \mathrm{~m} \mathrm{~s}^{-1}$, but exceeds $40 \mathrm{~m} \mathrm{~s}^{-1}$ on some days. For $10-\mathrm{m}$ winds, the statistics show strong winds exceeding $20 \mathrm{~m} \mathrm{~s}^{-1}$ for about 12 days per winter, on average, with a large interannual variability. A relatively strong correlation is found between the winds at the exit of Smith Sound and the SIC, indicating the relevance of channelled winds in Nares Strait to the formation of the NOW, which is also associated with strong air-ocean exchange (the mean sensible heat flux in that area amounts up to $200 \mathrm{~W} \mathrm{~m}^{-2}$ for December-February).

We analysed the gap flow dynamics for Smith Sound with respect to the $\mathrm{Fr}_{m}$ upstream of the gap, following
Gaberšek \& Durran's concept (2004). The LLJ core speed distribution depends on $\mathrm{Fr}_{m}$ with increasing wind speeds and LLJ height with increasing $\mathrm{Fr}_{m}$. Gaberšek \& Durran (2004) found a dependence of the LLJ position on $F r_{m^{\prime}}$ with a shift to the gap exit for $F r_{m}$ around 1 resulting from the interaction of the channelling and the mountain wave. This agrees with the present climatology, but the wind maximum is located south of the gap also for small $\mathrm{Fr}_{m}$ for Smith Sound. The pressure gradient at the exit of Smith Sound associated with the low over Melville Bay leads to an enhancement of the wind speed south of Smith Sound for all $\mathrm{Fr}_{m}$ values.

\section{Conclusions}

Channelled winds in Nares Strait are strongly related to the formation of the NOW, which is the largest ice-producing polynya in the Arctic. The climatology of topographically generated LLJs in Nares Strait underlines the need for high-resolution, long-term simulations for understanding the relevance of this phenomenon to sea-ice and ocean processes. The resolution of state-ofthe-art reanalyses, such as ERA5, is not sufficient to adequately describe the LLJs. An even higher resolution than that used in this study is desirable to capture the structure of the gap flow in more detail. Heinemann (2018) offered a detailed analysis of four LLJ cases in the Smith Sound area by an aircraft study in June 2010. A comparison of CCLM simulations at a 1 -km-scale resolution with these observations will be presented in a forthcoming publication. 


\section{Acknowledgements}

The authors thanks Lukas Schefczyk, Rolf Zentek and Oliver Gutjahr for support with the CCLM. They also thank the Climate Limited-area Modelling Community and the German Meteorological Service for providing the basic COSMO-CLM model. The AMSR-E sea-ice data were provided by the University of Bremen, ERA-Interim by the ECMWF and the PIOMAS data set by the Polar Science Center at the University of Washington. This work used resources of the Deutsches Klimarechenzentrum (DKRZ) granted by its Scientific Steering Committee (WLA) under project ID bb0474. ASR data were obtained from the Byrd Polar Research Center at Ohio State University. World Meteorological Organization observations were accessed at ftp://ftp.ncdc.noaa.gov/pub/data/noaa/isd-lite; GC-NET data were made available by Konrad Steffen, Cooperative Institute for Research in Environmental Sciences at the University of Colorado Boulder.

\section{Disclosure statement}

The authors report no potential conflict of interest.

\section{Funding}

This research work was part of the German-Russian collaborative project WTZ RUS: Changing Arctic Transpolar System, funded by the Federal Ministry of Education and Research (BMBF) under grant no. 03F0776D. The publication was funded by the Open Access Fund of the University of Trier and the German Research Foundation (DFG) within the Open Access Publishing funding programme.

\section{References}

Andreas E.L., Claffy K.J. \& Makshtas A.P. 2000. Lowlevel atmospheric jets and inversions over the western Weddell Sea. Boundary Layer Meteorology 97, 459-486, doi: 10.1023/A:1002793831076.

Barstad I. \& Adakudlu M. 2011 . Observation and modelling of gap flow and wake formation on Svalbard. Quarterly Journal of the Royal Meteorological Society 137, 1731-1738, doi: 10.1002/qj.782.

Bromwich D.H., Wilson A.B., Bai L.S., Liu Z., Barlage M., Shih C.-F., Maldonado S., Hines K.M., Wang S.-H., Woollen J., Kuo B., Lin H.C., Wee T.-K., Serreze M.C. \& Walsh J.E. 2018. The Arctic System Reanalysis version 2. Bulletin of the American Meteorological Society 99, 805-828, doi: 10.1175/BAMS-D-16-0215.1.

Bromwich D.H., Wilson A.B., Bai L.S., Moore G.W.K. \& Bauer P. 2016. A comparison of the regional Arctic System Reanalysis and the global ERA-Interim Reanalysis for the
Arctic. Quarterly Journal of the Royal Meteorological Society 142, 644-658, doi: 10.1002/qj.2527.

Dee D.P., Uppala S.M., Simmons A.J., Berrisford P., Poli P., Kobayashi S., Andrae U., Balmaseda M.A., Balsamo G., Bauer P., Bechtold P., Beljaars A.C.M., van de Berg L., Bidlot J., Bormann N., Delsol C., Dragani R., Fuentes M., Geer A.J., Haimberger L., Healy S.B., Hersbach H., Hólm E.V., Isaksen L., Kållberg P., Köhler M., Matricardi M., McNally A.P., Monge-Sanz B.M., Morcrette J.-J., Park B.-K., Peubey C., de Rosnay P., Tavolato C., Thépaut J.-N. \& Vitart F. 2011. The ERA-Interim Reanalysis: configuration and performance of the data assimilation system. Quarterly Journal of the Royal Meteorological Society 137, 553-597, doi: 10.1002/qj.828.

Doms G., Förster J., Heise E., Herzog H., Raschendorfer M., Reinhardt T., Ritter B., Schrodin R., Schulz J.P. \& Vogel G. 2011. A description of the Nonhydrostatic Regional COSMO-Model. Part II: physical parameterization. Offenbach, Germany: Consortium for Small-scale Modelling.

Doyle J.D. \& Shapiro M. 1999. Flow response to large-scale topography: the Greenland tip jet. Tellus Series A 51, 728748, doi: 10.3402/tellusa.v5li5.14471.

DuVivier A.K. \& Cassano J.J. 2013. Evaluation of WRF Model Resolution on simulated mesoscale winds and surface fluxes near Greenland. Monthly Weather Review 141, 941-963, doi: 10.1175/MWR-D-12-00091.1.

Gaberšek S. \& Durran D.R. 2004. Gap flows through idealized topography. Part I: forcing by large scale winds in the nonrotating limit. Journal of the Atmospheric Sciences 61, 2846-2862, doi: 10.1175/JAS-3340.1.

Gutjahr O. \& Heinemann G. 2018. A model-based comparison of extreme winds in the Arctic and around Greenland. International Journal of Climatology 38, 5272-5292, doi: 10.1002/joc. 5729 .

Gutjahr O., Heinemann G., Preusser A., Willmes S. \& Drüe C. 2016. Quantification of ice production in Laptev Sea polynyas and its sensitivity to thin-ice parameterizations in a regional climate model. The Cryosphere 10, 2999-3019, doi: 10.5194/tc-10-2999-2016.

Harden B.E., Renfrew I.A. \& Petersen G.N. 2011. A climatology of wintertime barrier winds off southeast Greenland. Journal of Climate 24, 4701-4717, doi: 10.1175/2011JCLI4113.1.

Heinemann G. 1999. The KABEG'97 field experiment: an aircraft-based study of the katabatic wind dynamics over the Greenlandic ice sheet. Boundary Layer Meteorology 93, 75-116, doi: 10.1023/A:1002009530877.

Heinemann G. 2004. Local similarity properties of the continuously turbulent stable boundary layer over Greenland. Boundary Layer Meteorology 122, 283-305, doi: 10.1023/B:B OUN.0000027908.19080.b7.

Heinemann G. 2018. An aircraft-based study of strong gap flows in the Nares Strait, Greenland. Monthly Weather Review 146, 3589-3604, doi: 10.1175/MWR-D-18-0178.1.

Heinemann G. 2020. Assessment of regional climate model simulations of the katabatic boundary layer structure over Greenland. Atmosphere 11, article no. 571, doi: 10.3390/ atmos 11060571. 
Heinemann G. \& Klein T. 2002. Modeling and observations of the katabatic flow dynamics over Greenland. Tellus Series A 54, 542-544, doi: 10.3402/tellusa.v54i5.12167.

Heinemann G., Willmes S., Schefczyk L., Makshtas A., Kustov V. \& Makhotina I. 2021. Observations and simulations of meteorological conditions over Arctic thick sea ice in late winter during the Transarktika 2019 expedition. Atmosphere 12, article no. 174, doi: 10.3390/ atmos 12020174.

Hersbach H., de Rosnay P., Bell B., Schepers D. \& Simmons A., Soci C., Abdalla S., Alonso-Balmaseda M., Balsamo G.; Bechtold P., Berrisford P., Bidlot J., de Boisséson E., Bonavita M., Browne P., Buizza R., Dahlgren P., Dee D., Dragani R., Diamantakis M., Flemming J., Forbes R., Geer A., Haiden T., Hólm E., Haimberger L., Hogan R., Horányi A., Janisková M., Laloyaux P., Lopez P., MuñozSabater J., Peubey C., Radu R., Richardson D., Thépaut J.-N., Vitart, Yang X., Zsoter \& Zuo H. 2018. Operational global reanalysis: progress, future directions and synergies with NWP. ERA Report Series 27. Reading: European Centre for Medium Range Weather Forecasts. doi: 10.21957/ tkic6g3wm.

Hughes M. \& Cassano J.J. 2015. The climatological distribution of extreme Arctic winds and implications for ocean and sea ice processes. Journal of Geophysical ResearchAtmospheres 120, 7358-7377, doi: 10.1002/2015JD023189.

Jakobson L., Vihma T., Jakobson E., Palo T., Männik A. \& Jaagus J. 2013. Low-level jet characteristics over the Arctic Ocean in spring and summer. Atmospheric Chemistry and Physics 13, 11089-11099, doi: 10.5194/ acp-13-11089-2013.

Kohnemann S.H.E., Heinemann G., Bromwich D.H. \& Gutjahr O. 2017. Extreme warming in the Kara Sea and Barents Sea during the winter period 2000 to 2016. Journal of Climate 30, 8913-8927, doi: 10.1175/JCLI-D-16-0693.1.

Køltzow M. 2007. The effect of a new snow and sea ice albedo scheme on regional climate model simulations. Journal of Geophysical Research-Atmospheres 112, D07110, doi: 10.1029/2006JD007693.

Melling H. 2011. The best laid schemes: a Nares Strait adventure. Oceanography 24, 124-125, doi: 10.5670/ oceanog.2011.63.

Moore G.W.K. \& Renfrew I.A. 2005. Tip jets and barrier winds: a QuickSCAT climatology of high wind speed events around Greenland. Journal of Climate 18, 37133725, doi: 10.1175/JCLI3455.1.

Moore G.W.K., Renfrew I.A., Harden B.E. \& Mernhild S.H. 2015. The impact of resolution on the representation of southeast Greenland barrier winds and katabatic flows. Geophysical Research Letters 42, 3011-3018, doi: 10.1002/2015GL063550.

Moore G.W.K. \& Våge K. 2018. Impact of the model resolution on the representation of the air-sea interaction associated with the North Water Polynya. Quarterly Journal of the Royal Meteorological Society 144, 1474-1489, doi: 10.1002/ qj. 3295.

Münchow A., Melling H. \& Falkner K.K. 2006. An observational estimate of volume and freshwater flux leaving the Arctic Ocean through Nares Strait. Journal of Physical Oceanography 36, 2025-2041, doi: 10.1175/JPO2962.1.

Overland J.E. 1984. Scale analysis of marine winds in straits and along mountain coasts. Monthly Weather Review 112, 2530-2534, doi: 10.1175/1520-0493(1984)112<2530:SA OMWI $>2.0 . \mathrm{CO} ; 2$.

Petersen G.N., Renfrew I.A. \& Moore G.W.K. 2009. An overview of barrier winds off southeastern Greenland during the Greenland Flow Distortion experiment. Quarterly Journal of Royal Meteorological Society 135, 1950-1967, doi: 10.1002/qj.455.

Preusser A., Heinemann G., Willmes S. \& Paul S. 2015. Multi-decadal variability of polynya characteristics and ice production in the North Water Polynya by means of passive microwave and thermal infrared satellite imagery. Remote Sensing 7, 15844-15867, doi: 10.3390/ rs71215807.

Preusser A., Heinemann G., Willmes S. \& Paul S. 2016. Circumpolar polynya regions and ice production in the Arctic: results from MODIS thermal infrared imagery from $2002 / 2003$ to $2014 / 2015$ with a regional focus on the Laptev Sea. The Cryosphere 10, 3021-3042, doi: 10.5194/ tc-10-3021-2016.

Rockel B., Will A. \& Hense A. 2008. The regional climate model COSMO-CLM (CCLM). Meteorologische Zeitschrift 17, 347-348, doi: 10.1127/0941-2948/2008/0309.

Samelson R.M., Agnew T., Melling H. \& Münchow A. 2006. Evidence for atmospheric control of sea-ice motion through Nares Strait. Geophysical Research Letters 33, L02506, doi: 10.1029/2005GL025016.

Samelson R.M. \& Barbour P.L. 2008. Low-level jets, orographic effects and extreme events in Nares Strait: a model-based mesoscale climatology. Monthly Weather Review 136, 4746-4759, doi: 10.1175/2007MWR2326.1.

Schroeder D., Heinemann G. \& Willmes S. 2011 . The impact of a thermodynamic sea-ice module in the COSMO numerical weather prediction model on simulations for the Laptev Sea, Siberian Arctic, Polar Research 30, article no. 6334, doi: 10.3402/polar.v30i0.6334.

Sedlar J., Tjernström M., Rinke A., Orr A., Cassano J., Fettweis X., Heinemann G., Seefeldt M., Solomon A., Matthes H., Phillips T. \& Webster S. 2020. Confronting Arctic troposphere, clouds, and surface energy budget representations in regional climate models with observations. Journal of Geophysical Research-Atmospheres 124, article no. e2019JD031783, doi: 10.1029/2019JD031783.

Sharp J. \& Mass C.F. 2004. Columbia Gorge gap winds: their climatological influence and synoptic evolution. Weather and Forecasting 19, 970-992, doi: 10.1175/826.1.

Spreen G., Kaleschke L. \& Heygster G. 2008. Sea ice remote sensing using AMSR-E 89-GHz channels. Journal of Geophysical Research-Oceans 113, C02S03, doi: 10.1029/2005JC003384.

Steffen K., Box J.E. \& Abdalati W. 1996. Greenland Climate Network: GC-Net. CRREL Special Report 96-27, 98-103.

Yao T. \& Tang C.L. 2003. The formation and maintenance of the North Water Polynya. Atmosphere-Ocean 41, 187-201, doi: $10.3137 /$ ao.410301. 
Zentek R. \& Heinemann G. 2020. Verification of the regional atmospheric model CCLM v5.0 with conventional data and Lidar measurements in Antarctica. Geoscientific Model Development 13, 1809-1825, doi: 10.5194/ gmd-13-1809-2020.

Zhang J. \& Rothrock D.A. 2003. Modeling global sea ice with a thickness and enthalpy distribution model in generalized curvilinear coordinates. Monthly Weather Review 131, 845-861, doi: 10.1175/1520-0493(2003)131<0845:MGSI $\mathrm{WA}>2.0 . \mathrm{CO} ; 2$.

\section{Satellite and model data}

EUMETSAT SAF on Ocean and Sea Ice 2016. Global sea ice concentration climate data record release 1.1 (period 1978-2009)—DMSP. OSI SAF. doi: 10.15770/ EUM_SAF_OSI_0001.

Copernicus Climate Change Service (C3S) 2017. ERA5: fifth generation of ECMWF atmospheric reanalyses of the global climate. Copernicus Climate Change Service Climate Data Store, 2019. Accessed on the internet at https://cds.climate.copernicus.eu/cdsapp\#!/home on 15 October 2019.

National Center for Atmospheric Research/University Corporation for Atmospheric Research, and Polar Meteorology Group/Byrd Polar and Climate Research Center/ The Ohio State University 2017. Arctic System Reanalysis version 2. Research Data Archive at the National Center for Atmospheric Research, Computational and Information Systems Laboratory. Accessed on the internet at https://doi. org/10.5065/D6X9291B on 01 August 2017/ 25 July 2018. 